\title{
Complementing PABITRA High-Island Studies by Examining Terrestrial Plant Diversity on Atolls ${ }^{1}$
}

\author{
K. W. Bridges ${ }^{2,3}$ and Will McClatchey ${ }^{3}$
}

\begin{abstract}
The Pacific-Asia Biodiversity Transect (PABITRA) studies are based on a network of high-island biodiversity sites. These sites are structurally and historically complex. The majority of Pacific islands, in contrast, are low atolls with a common and simple flora and structure. As a result, atolls may serve as "controls" that may provide a way to assess impact of the upland high-island ecosystems on coastal regions of Pacific islands. Atoll studies can complement the PABITRA network because the gateway sites are near each other or separated from one another by one or more atolls. Such an addition will enhance interpretation of high-island ecosystems and their coastal zones because ecosystem surveys can be conducted quickly and accurately in atoll environments. We present results from quantitative studies of plant diversity from seven islets at Ailinginae Atoll in the northern Marshall Islands and discuss the value of this methodology as a way to enhance interpretation of the PABITRA data.
\end{abstract}

The Pacific-Asia Biodiversity Transect (PABITRA) sites provide for collaborative investigations of the biodiversity on a series of islands in the Pacific. The sites were specifically chosen on several tropical high islands across several Pacific transects so that upland and lowland areas could be viewed as an integrated system. We support the choice of these focal sites, but we propose that they be supplemented with the addition of atoll sites. This expanded network will provide a broader range of opportunities to understand the function and structure of island ecosystems, including the role of people in these settings, while adding little additional cost to the overall project.

The PABITRA participants have a wide range of research goals. Many of these focus on analyses of the indigenous forests and range from assessing their value as ecological reserves and the preservation of endemic spe-

\footnotetext{
${ }^{1}$ Manuscript accepted 21 April 2004.

${ }^{2}$ Corresponding author.

${ }^{3}$ Department of Botany, University of Hawaici at Mānoa, Honolulu, Hawai`i 96822.
}

Pacific Science (2005), vol. 59, no. 2:261-272

(C) 2005 by University of Hawai'i Press

All rights reserved cies through appraising the watershed services that support the human populations. Atoll vegetation serves similar functions but operates without the topographic complexity or species richness of the high islands.

There are obvious differences when atoll vegetation is compared with the more structurally complex vegetation found in the high islands, particularly in the upland areas. But it is comparisons of atoll communities with coastal communities of islands that are likely to be most interesting and perhaps most productive. A careful selection of sites may permit an evaluation of many types of relationships between upland and coastal areas because the atoll areas can serve as a control (without the upland area), particularly as this includes assessments of the resources needed to support human populations.

We are certainly not the first investigators to propose the value of atolls and their small constituent islets as key elements in comparative island analyses. MacArthur and Wilson's (1967) study has become a controversial classic (Stoddart 1992) in its predictions of trends in species richness over a range of island sizes. Such comparisons are not simple, of course, because high islands and atolls differ in many fundamental ways, such as their geologic history and the development of their soils.

The PABITRA network provides many 
opportunities to include atolls. In the northern transect, for example, which crosses the Pacific from Belau (Palau) to Hawai'i, there are hundreds of atolls dispersed near and between proposed high-island study areas. Indeed, most of the islands along this transect are atolls. As a result, it is possible to match high islands with atolls that share similar sealevel rainfall and that occur at similar latitudes.

This study was designed, in part, to demonstrate the practicality of including atolls in the PABITRA design. In particular, we wanted to demonstrate that appropriate assessments could be done quickly and with a small research team.

Our research broadly involves the terrestrial plant biodiversity of Ailinginae, the westernmost atoll in the Rongelap Atoll group in the Republic of the Marshall Islands (Figure 1). We established five general objectives: (1) obtain a complete inventory of the terrestrial plant species and collect vouchers of each species on each islet; (2) document the distribution of plants on the islets and collect information on the general structure of the vegetation; (3) determine the sampling efficiency of species data collected on random transects relative to a general checklist survey approach; (4) collect any botanical evidence of the locations and types of past anthropogenic activities; (5) build a baseline set of information that can be used for future studies. The specific hypotheses we wanted to address were as follows: (1) The same species are found on an islet if you use transect sampling or a "check listing" method (in chapter 3, "Vegetation" by D. Mueller-Dombois, J. D. Jacobi, and C. C. Daehler, in Biodiversity Assessment of Tropical Island Ecosystems, PABITRA Manual for Interactive Ecology and Management [D. Mueller-Dombois, K. W. Bridges, and C. C. Daehler, eds.] scheduled tentatively for publication in 2005; the book contents are available at http://www.botany.hawaii.edu/ pabitra) of thoroughly examining an islet. (2) The islets in the atoll have the same species. (3) Anthropogenic disturbances are found on all the larger islets.

The opportunity to do this study came about when the Rongelap Atoll Local Gov- ernment decided it was interested in setting aside some lands for conservation. This process required basic resource surveys, and the U.S. Fish and Wildlife Service in conjunction with the U.S. Department of the Interior were contacted for logistical, financial, and scientific support. Personnel from the University of Hawai'i at Mānoa were included as part of the basic research team, along with individual members from several other academic institutions. Most of the financial and logistical support came from the Rongelap Atoll Local Government. They were able to secure a suitable ship, ship crew, small support vessels, dive master, and field assistants. Immediately after the expedition, the Rongelap Atoll Local Government, in cooperation with the government of the Republic of the Marshall Islands, began the process of establishing Ailinginae Atoll as the first national park of the Marshall Islands. They are also considering applying for United Nations Educational, Scientific, and Cultural Organization (UNESCO) World Heritage Site status.

\section{Study Area}

Rongelap Atoll is the administrative center of a group of three atolls (Rongelap, Ailinginae, and Rongerik) and the only one of these atolls that has a recent history of permanent habitation. Ailinginae Atoll is approximately 13 $\mathrm{km}$ to the west-southwest of Rongelap Atoll and about $30 \mathrm{~km}$ from the main southern entrance to Rongelap lagoon (Figure 1). Small numbers of people from Rongelap are known to have visited Ailinginae periodically and stayed there for short periods. There have been few, if any, visitors to this atoll in the past 50 yr except for our expedition.

Ailinginae Atoll consists of small islets arranged on three sides of a lagoon that is roughly rectangular. The east-west length is approximately $25 \mathrm{~km}$, and it is about $6.5 \mathrm{~km}$ at the widest points. The larger islets are generally found along the southern and eastern edges of the lagoon. The general appearance of one of the larger islets, Mogiri Islet, is shown in Figure 2. The northern edge of the atoll is mostly a sand bar that is overwashed by waves (Figure 1). The lagoon can be quite 


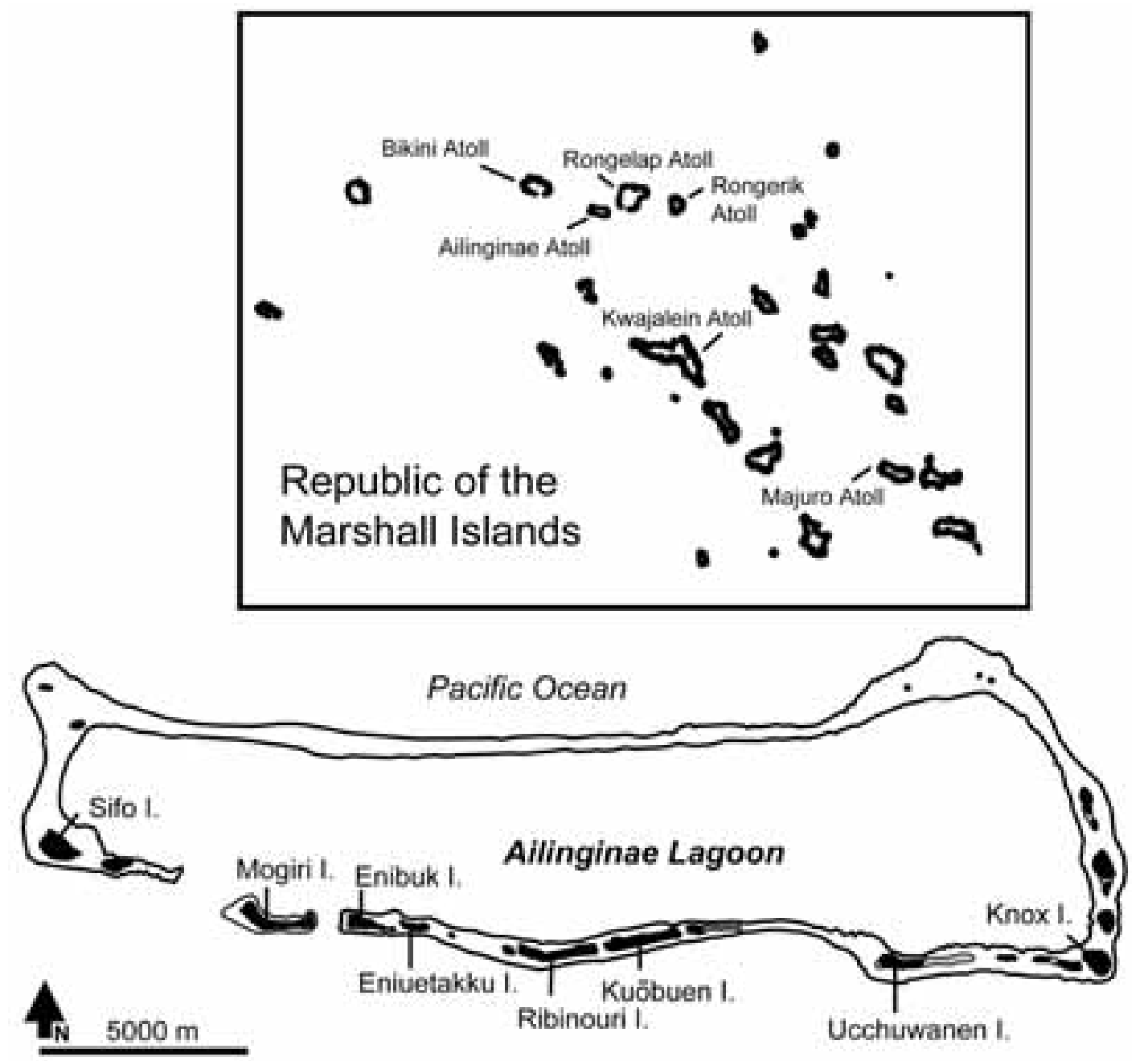

Figure 1. Distribution of study islets at Ailinginae Atoll.

rough as a result of the exposure to waves from the north and the general length of the lagoon along the dominant wind direction. This provides more shoreline wave action on the lagoon side of the southern islets than would be expected if the lagoon were smaller and more fully enclosed. The islet names used here correspond to those given on the DMA (1995) map of the atoll. Marshallese names were elicited from members of the Rongelap Atoll Local Government and are provided for reference in Table 1.
Studies were done primarily on seven islets: Sifo, Mogiri, Enibuk, Eniuetakku, Ribinouri, Kuōbuen, and Knox. A brief visit was also made to Ucchuwanen Islet. Air photos are available for Ailinginae Atoll and these were used to measure the area of each islet studied, as well as its length and width. The land areas and axis dimensions, excluding sand spits, of the primary islets are given in Table 1 . The average area of the seven islets is 29.6 ha, with Eniuetakku (9.0 ha) the smallest and Ribinouri (49.2 ha) the largest. The 


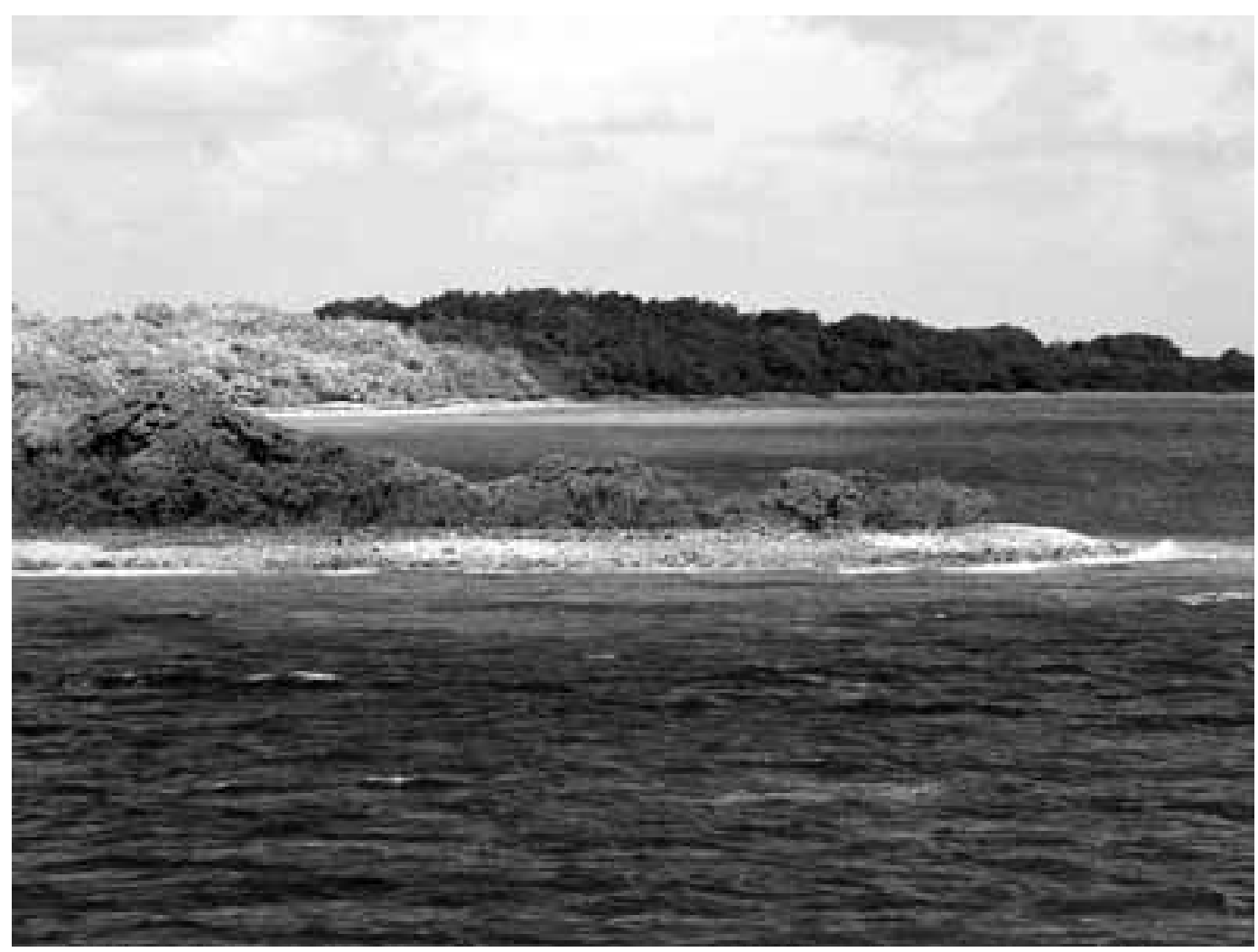

Figure 2. The lagoon side of Mogiri Islet, a typical representative of a larger islet at Ailinginae Atoll, viewed from Eniibukku Pass.

length/width ratio is a rough measure of the shape of an islet. Two are fairly round, Knox (1.5) and Sifo (1.9), but most are long and narrow with a value of 6.0 or larger.

\section{MATERIALS AND METHODS}

The research expedition was made up of separate teams for terrestrial and marine plant and animal surveys. Only the terrestrial vascular plant survey is reported here.

Three methods were employed, as follows: a quantitative plant survey using transects, a general plant checklist survey on each islet, and an ethnographic survey. Regression statistics were calculated using the SAS (version 6.12) GLM procedure (SAS Institute, Inc. 1995).

\section{Quantitative Transect Survey}

It should be noted that the transect methodology describes the activities carried out on this expedition, even though only part of the data collected is included in this report. The vegetation structure and pattern will be presented elsewhere.

Transects were based on a set of air photos, with scales, of seven of the largest islets. A line was drawn through the long axis of each islet, and one point was randomly located along this line for each $250 \mathrm{~m}$ of islet length. This resulted in three points on each islet except Enibuk, which required four points. Transects were oriented to run north to south through these points, except for the easternmost islet (Knox), on which transects 
ran west to east. As a result, all transects ran from the lagoon edge to the ocean coastline.

Transect locations marked on the air photos served as guides for visually determining transect starting locations. The actual transect start and end points were recorded with a WAAS-corrected (Wide Area Augmentation System) GPS (Global Positioning System) (Garman eTrex Vista) reading. GPS tracks were also recorded for about half the transects so that typical transect routes could be checked.

The research design resulted in 22 transects that averaged $234 \mathrm{~m}$ long, with a total length of $5,047 \mathrm{~m}$. Transects covered approximately $2.4 \%$ of the total area of the islets surveyed.

Transects were marked by running a cord through the vegetation following a compass line. This cord established one side of a 1-mwide transect. Following the transect line, each species occurrence was recorded along with its starting location (linear distance estimated from the location of the previous plant). Any plant that was rooted inside the transect or that overlapped from the right side was included (those rooted outside the transect or overlapping from the left were excluded). An estimate was made of the stem diameter (at breast height for taller-stature plants), total height, and canopy spread of every fourth individual occurrence of each species. Transects were run with two teams of two persons each. Species identification, plant size, and distance estimates were compared for consistency by using a calibration transect with all team members participating. The results were recorded on a field-data form and transferred to a spreadsheet for analysis. Three of the five individuals participating were very familiar with the flora. The terrestrial plant survey was done on five consecutive days starting on 3 June 2002.

\section{Plant Checklist Survey}

One researcher from the terrestrial plant team made a checklist survey of all vascular plant species found on each islet. The time available for this inventory was limited to the period during which the other members of the team gathered data from the transects. The checklist survey involved visiting as many different environments as could be found on each islet including the coastal scrub, open areas in the forest, areas with the tallest forest, areas with emergent coconut trees, and areas with birds seen overhead. Voucher specimens of each species encountered were collected on each islet along with a set of photographs of each species and habitats found on each islet.

In addition, an inventory was taken of Ucchuwanen Islet, with vouchers prepared of Boerhavia tetandra, Cassytha filiformis, Cocos nucifera, Cordia subcordata, Laportea ruderalis, Guettarda speciosa, Ipomoea alba, Lepturus repens, Morinda citrifolia, Pandanus tectorius, Pemphis acidula, Pisonia grandis, Scaevola sericea, Suriana maritima, and Tournefortia argentea. Time did not permit surveying of the transects planned for this islet. Therefore, the species compilation from Ucchuwanen is not included in the distribution studies because its methodology was not comparable with that used on the other seven islets.

\section{Ethnographic Survey}

Ethnographic interviews were conducted with three elderly members of the Rongelap community who had periodically lived on Ailinginae before World War II. These were the only individuals in the local population who were old enough and had any recollections of the islands. Interviews were conducted using open-ended questions asking about plants used, daily activities, names of islets and their resources, and locations of temporary settlements. Those interviewed were collaborators in organizing the research. They initially volunteered to share information without being asked. These local leaders were eager to see the traditional human element of Ailinginae recognized along with the biological data that were being gathered.

\section{RESULTS}

A total of 29 species was found at Ailinginae Atoll (Table 1) based on a combination of 
TABLE 1

Ailinginae Terrestrial Vascular Plant Species by Islet

\begin{tabular}{|c|c|c|c|c|c|c|c|c|}
\hline \multirow[b]{4}{*}{ Taxa } & \multirow[b]{4}{*}{$\begin{array}{l}\text { Life } \\
\text { Form }\end{array}$} & \multicolumn{7}{|c|}{ Map Islet Name } \\
\hline & & $\stackrel{0}{\sharp ~}$ & $\begin{array}{l}\bar{E} \\
\sum_{0}^{0}\end{array}$ & $\begin{array}{l}\text { 岂 } \\
\stackrel{0}{0} \\
\text { 鳬 }\end{array}$ & 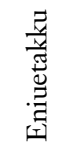 & 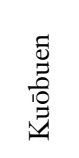 & 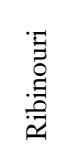 & 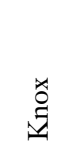 \\
\hline & & \multicolumn{7}{|c|}{ Traditional Islet Name } \\
\hline & & 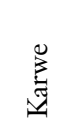 & $\begin{array}{l}\frac{\bar{g}}{3} \\
\frac{\pi}{\pi}\end{array}$ & 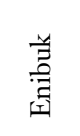 & 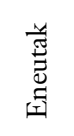 & 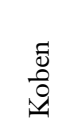 & $\begin{array}{l}\dot{0} \\
\stackrel{0}{0} \\
\ddot{0}\end{array}$ & . \\
\hline Islet Area (ha) & & 27.9 & 41.1 & 19.0 & 9.0 & 28.8 & 49.2 & 32.1 \\
\hline Length/Width Ratio & & 1.9 & 6.6 & 3.0 & 6.0 & 8.0 & 7.2 & 1.5 \\
\hline Boerhavia diffusa $\mathrm{L}$. & Herb & $\mathrm{C}$ & $\mathrm{C}$ & & & B & & B \\
\hline Boerhavia tetandra Forster $\mathrm{f}$. & Herb & B & B & B & B & B & $\mathrm{B}$ & $\mathrm{B}$ \\
\hline Calophyllum inophyllum L. & Tree & $\mathrm{C}$ & & & & & & \\
\hline Cassytha filiformis $\mathrm{L}$. & Vine & B & $\mathrm{C}$ & B & B & & $\mathrm{C}$ & $\mathrm{T}$ \\
\hline Clerodendron inerme (L.) Gaertner & Vine & B & & & & & & B \\
\hline Cocos nucifera $\mathrm{L}$. & Tree & B & & B & $\mathrm{T}$ & & B & $\mathrm{B}$ \\
\hline Cordia subcordata Lam. & Tree & B & $\mathrm{T}$ & $\mathrm{B}$ & $\mathrm{T}$ & B & $\mathrm{B}$ & $\mathrm{B}$ \\
\hline Digitaria pruriens (Trin.) Buese & Grass & $\mathrm{C}$ & & $\mathrm{C}$ & & & & \\
\hline Fimbristylis cyanosa $\mathrm{R}$. Br. & Herb & & & & $\mathrm{C}$ & & & \\
\hline Guettarda speciosa L. & Tree & B & B & B & B & B & B & B \\
\hline Ipomoea alba $\mathrm{L}$. & Vine & $\mathrm{T}$ & B & B & B & & B & B \\
\hline Laportea ruderalis (Forst.) Chew & Herb & B & B & B & B & B & B & B \\
\hline Lepturus repens (Forster f.) R. Br. & Grass & B & B & B & B & $\mathrm{C}$ & B & B \\
\hline Morinda citrifolia $\mathrm{L}$. & Tree & B & $\mathrm{C}$ & B & B & $\mathrm{C}$ & & $\mathrm{T}$ \\
\hline $\begin{array}{l}\text { Neisosperma oppositifolium (Lam.) } \\
\text { Fosb. \& Sachet }\end{array}$ & Tree & & & & & & & $\mathrm{B}$ \\
\hline Pandanus tectorius Sol. ex Parkinson & Tree & B & B & B & $\mathrm{T}$ & & & B \\
\hline Pemphis acidula Forster & Tree & B & $\mathrm{C}$ & B & B & B & B & B \\
\hline $\begin{array}{l}\text { Phymatosorus grossus (Langsol. \& } \\
\text { Fisch.) Brownlie }\end{array}$ & Fern & B & B & B & $\mathrm{T}$ & $\mathrm{C}$ & B & B \\
\hline Pisonia grandis $\mathrm{R}$. Br. & Tree & B & B & B & B & B & B & B \\
\hline Portulaca lutea Sol. & Herb & $\mathrm{C}$ & $\mathrm{C}$ & & B & & $\mathrm{T}$ & B \\
\hline Scaevola sericea Vahl & Shrub & $\mathrm{B}$ & $\mathrm{B}$ & B & $\mathrm{B}$ & $\mathrm{T}$ & B & $\mathrm{B}$ \\
\hline Soulamea amara Lam. & Tree & & & & & & & $\mathrm{C}$ \\
\hline Suriana maritima $\mathrm{L}$. & Tree & B & B & B & B & B & B & $\mathrm{T}$ \\
\hline Tacca leontopetaloides (L.) Merr. & Herb & B & & & & & & $\mathrm{C}$ \\
\hline Terminalia litoralis Seemann & Tree & & $\mathrm{C}$ & $\mathrm{C}$ & $\mathrm{C}$ & $\mathrm{C}$ & & \\
\hline Thuarea involuta (Forster f.) R. Br. & Grass & $\mathrm{C}$ & & & & & & \\
\hline Tournefortia argentea L.f. & Tree & $\mathrm{B}$ & B & $\mathrm{B}$ & $\mathrm{B}$ & B & B & $\mathrm{B}$ \\
\hline Triumfetta procumbens Forster $\mathrm{f}$. & Vine & B & B & B & $\mathrm{T}$ & & & \\
\hline Wollastonia biflora (DC) L. & Herb & B & & & & & & \\
\hline Count & & 25 & 19 & 19 & 20 & 14 & 15 & 22 \\
\hline$\%$ of total species & & 86.2 & 65.5 & 65.5 & 69.0 & 48.3 & 51.7 & 75.9 \\
\hline
\end{tabular}

Key: B, found using both transect and checklist survey methods; T, found only with the transect method; C, found only with the checklist survey method. 


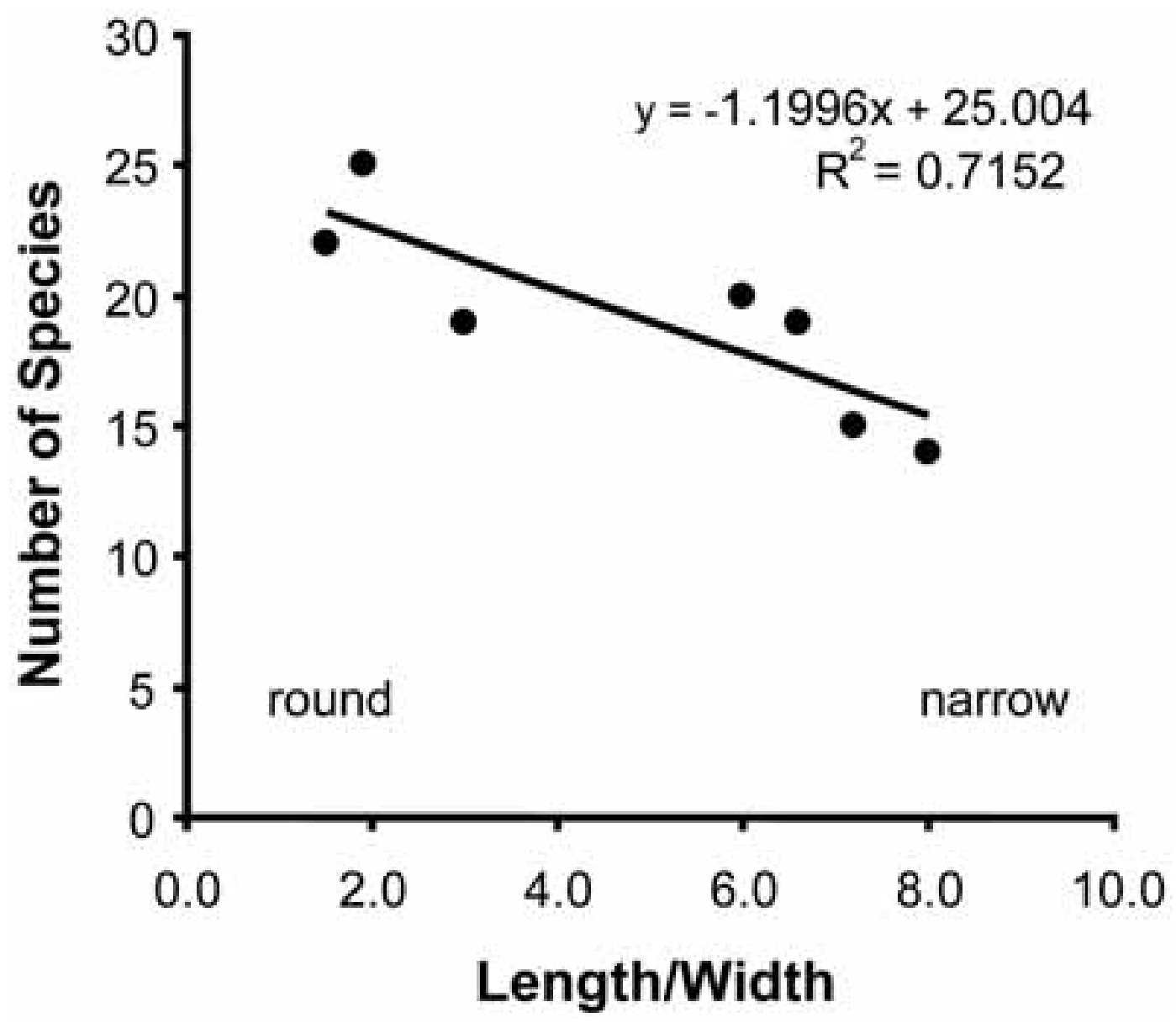

FIGURE 3. Species-islet shape relationship where shape is measured as the length to width ratio.

both survey methods. The seven islets had an average of 19.1 species ( $66 \%$ of the total) with a range from as few as $14(48 \%)$ on Kuōbuen to a maximum of $25(86 \%)$ on Sifo. Eleven species (38\%) were found on all islets. In contrast, six species (21\%) were found on only a single islet. A total of 211 voucher specimens was collected from Ailinginae representing 122 species instances (identifications of a particular species on a particular islet). Neither the checklist nor the transect method allowed the researchers to find all species. Our use of the checklist survey method produced a larger list of species (Table 1, symbol C) and identified 22 species instances that would have been missed by transects alone. Likewise, transects identified 12 species instances (Table 1 , symbol $\mathrm{T}$ ) that would have been missed using a checklist survey alone.

The number of species found on an islet is not related to the islet size because the slope of such a regression of islet size on the number of species is not significantly different from zero $\left(r^{2}=0.10, P=0.477\right)$. The shape of an islet, expressed as the ratio of the length and width, is significantly $\left(r^{2}=0.72, P=\right.$ 0.012 ) related to the number of species (Figure 3). Those islets that are "rounder" (i.e., have a lower length-width ratio) tend to have more species than those islets that are long and thin. 
Ethnographic results included verification and correction of names of islets (those used on most available maps are nonindigenous names), indications that the islets of Knox, Sifo, and possibly Enibuk had formerly been regular sites of human visits, and a list of Marshallese names for plants found on the islets. One of the elders accompanied the researchers during part of the work, identifying voucher specimens with indigenous names. He furthermore listed important crops, including some that were not found on any of the islets and one in particular that is not now known from Rongelap Atoll. This last plant was described as a "one-seeded pumpkin," possibly Sechium edule (Jacq.) Sw.

\section{DISCUSSION}

\section{Distribution of Species and General Structure per Islet}

Mueller-Dombois and Fosberg (1998) described the vegetation from the Marshall Islands (although not specifically from Ailinginae Atoll). Thomas et al. (1989) surveyed several atolls in the northern Marshall Islands and provided species lists of their findings. The general depictions in those reports match what we found in our survey, with only a few exceptions. These differences will be noted later. Muller and Vander Velde (2001) listed trees observed as well as those likely to be found throughout the Marshall Islands. Their list includes Ailinginae, although there is no reference of there having been a survey of the atoll. The speculation in their report on Ailinginae is interesting because they predict the presence of 12 species of trees, 11 of which we found. In addition, they did not predict the presence of four other species that we did find. It is likely that variation in species occurrences over a large area, such as the Marshall Islands, is influenced by the north-south rainfall gradient that results in the northern islands (such as Ailinginae Atoll) having a semiarid climate (Mueller-Dombois and Fosberg 1998), with a general annual rainfall range of $110 \mathrm{~cm}$ in the north and $350 \mathrm{~cm}$ in the south (Simon et al. 2002).
There were differences between the sets of species found on the seven islets and we must reject our second hypothesis of uniform composition. We found 11 species (representing only $38 \%$ of the total species) that occurred on all of the seven islets, with all but one (Phymatosorus grossus) found on the eighth islet (Ucchuwanen) that was not completely surveyed. These species can be seen as the baseline early colonization flora of Ailinginae Atoll: Boerbavia tetandra, Cordia subcordata, Laportea ruderalis, Guettarda speciosa, Lepturus repens, Phymatosorus grossus, Pemphis acidula, Pisonia grandis, Scaevola sericea, Suriana maritima, and Tournefortia argentea. Cassytha filiformis, Ipomoea alba, and Morinda citrifolia were each only lacking from one islet and therefore may represent the next phase in colonization of the Ailinginae islets. Cassytba and Ipomoea were patchy in their distributions, whereas Morinda, if present, was more widely distributed on an islet. Boerbavia diffusa, Portulaca lutea, and Triumfetta procumbens are all herbaceous species that were encountered only sporadically, although they were found on a majority of the islets. These species could have been overlooked in transects or inventories because of their size and rarity. Conversely, Cocos nucifera and Pandanus tectorius were not found on each islet but are conspicuous species that were unlikely to be missed if they were present. Cocos nucifera is likely near the limit of its distribution because it usually grows only in atoll areas where the annual rainfall is greater than $1 \mathrm{~m}$ (Stoddart 1992). Terminalia litoralis is a tree that, when not in fruit or flower, could be mistaken for one of several other common species if observed only passingly. This tree was found on four islets (interestingly, absent from Sifo and Knox) in small clusters of individuals that were not common. It is possible that these trees were missed at other islets by both transect and checklist surveys.

Despite a size range of almost five times, we did not find a relationship between the area and the number of species on an islet. This may be due to the small sample of islets and also because we did not include very small islets in our study. Stoddart (1992) similarly indicated that size is not a determinant 
of species richness in atoll vegetation; however his analysis is based on the scale of entire atolls, not individual islets.

The relationship between islet shape and species numbers (Figure 3 ) adds to the ecological factors (resource availability and the ecological properties of species) identified by Mueller-Dombois and Fosberg (1998) that influence species distributions on atolls. In our study, human habitation may contribute to this relationship because two of the "rounder" islets (Sifo and Knox) had evidence of anthropogenic activities. Six species were found on only one islet (five were found only on Sifo or Knox), and two species were found only on Sifo and Knox. These two roughly round islets are located respectively at the southwest and southeast corners of the atoll and may experience a different type of storm impact than do the less rounded islets along the southern side of the atoll between Sifo and Knox. Calophyllum inophyllum was found at Sifo as a single, large tree near the ocean side in the edge of the forest. Likewise, Soulamea amara and Neisosperma oppositifolium were found on Knox as a few larger trees grouped together.

Herbaceous sedge and grass species such as Fimbristylis and Digitaria are common at Rongelap and other nearby atolls (Taylor 1950) but were relatively uncommon at Ailinginae with one exception, Lepturus repens. The vine or spreading shrub Clerodendron inerme was found only in the most protected parts of the forests of Sifo and Knox. Likewise, Tacca leontopetaloides was only found in what were apparently old garden sites on Sifo and Knox.

Before conducting this expedition, the research team had worked for 6 months at Rongelap Atoll, becoming familiar with the forest structure, species diversity, and relative abundance. Only one species proved to be a surprise: Laportea ruderalis. This herbaceous annual was first encountered at Ailinginae, where it appeared to have only recently sprouted. It was not found on any islet at Rongelap before the work in Ailinginae but was noted on several Rongelap islets that were revisited after the work at Ailinginae. This case demonstrates that short-term sur- veys may miss otherwise common species because of their phenological pattern. Such periodicity may be due to seasonality or climatological changes.

\section{Evidence of Former Anthropogenic Activity}

We were not able to adequately test our hypothesis of anthropogenic disturbances. There were some signs of human influence, but our sampling scheme and time available to fully discuss the history of this atoll with people who knew its history were too limited to allow any meaningful conclusions. The only permanent man-made objects that we encountered at Ailinginae Atoll, both on Enibuk Islet, were a stone marker erected by the Japanese about $100 \mathrm{yr}$ before our visit and a concrete water cistern near the west end.

Evidence for gardens and other anthropogenic activities were seen in two forms. Several of the islets showed evidence of former coconut plantations: Enibuk, Eniuetakku, Ribinouri, and Ucchuwanen. The older coconut trees on each of these islets are planted in rows and younger trees form thickets in piles of unharvested coconuts around older trees. Coconuts found on Sifo and Knox did not appear to be planted in rows but rather appeared to be associated with human gardens containing Tacca leontopetaloides and Pandanus tectorius. One transect on Sifo happened to pass through such a garden (see Figure 4) where coconuts are mixed with other garden species. The presence of the garden can be seen in the abrupt shift from natural forest components on each side of the garden. It is interesting to note that the location of the garden is within the forest yet closer to the protected lagoon side of the islet.

\section{Expedition Structure}

This expedition included development, planning, funding, and logistical consideration that we believe are typically encountered when surveying a remote, uninhabited area that is far from normal transportation routes. In our case, we found that the full participation and support of the local government and people were essential to our success. 


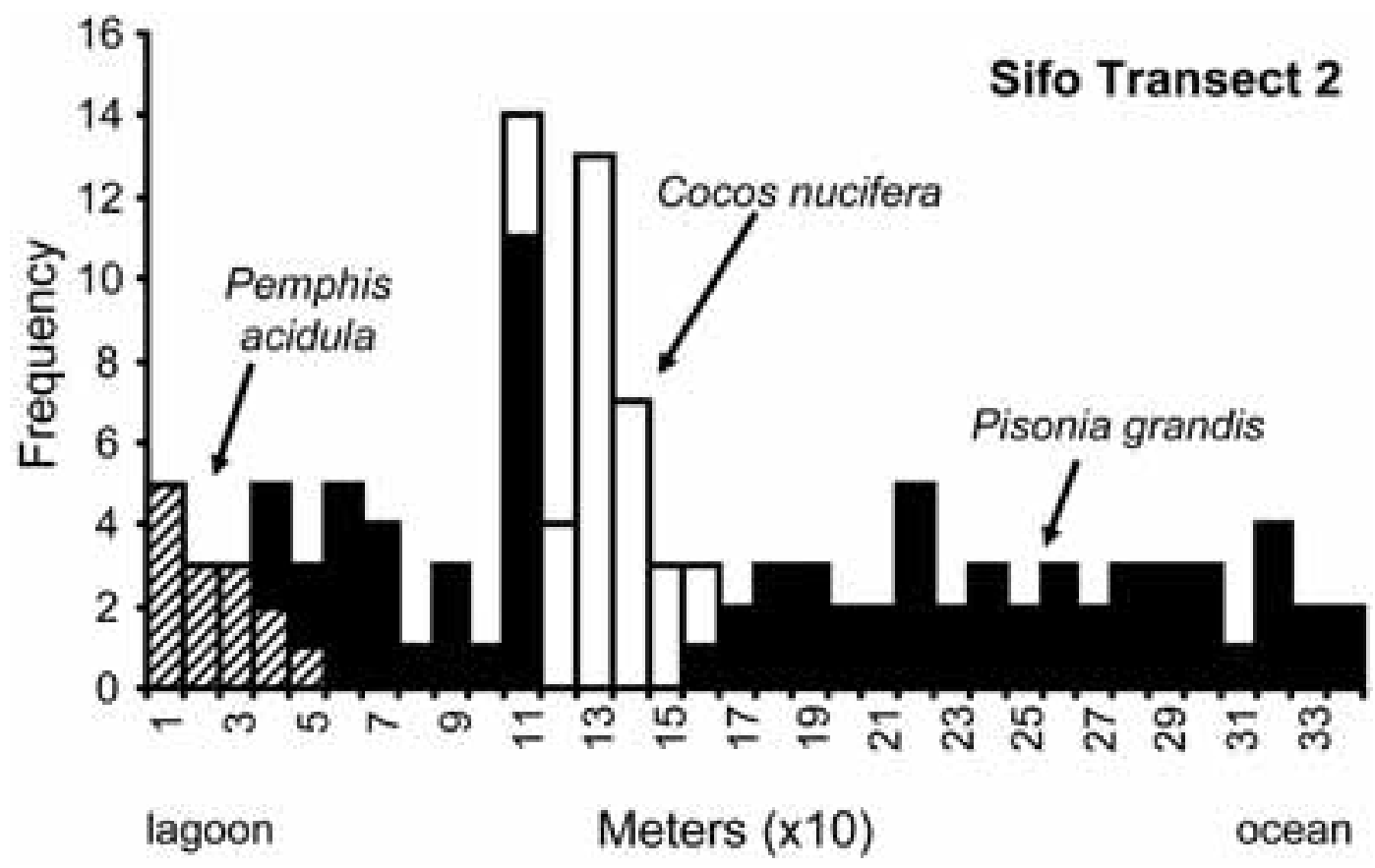

FIGURE 4. The frequency per $10 \mathrm{~m}$ of distance between lagoon and ocean of major tree species on Sifo Islet, transect 2.

The overall expedition was divided into two primary survey groups, marine and terrestrial, with about twice as many people involved in the marine activities. The terrestrial surveys were further divided into four teams; one focused on a survey of the perimeter of each islet (for mapping) while the other three did inventories of the turtles, birds, and plants. The expedition participants generally lived aboard an oceangoing tugboat (Ratak) and took small boats to specific survey areas. The ship conditions permitted the daily pressing of voucher specimens and drying in the air-conditioned environment, processing photographs, and entering collection and transect log data for analysis. These tasks are often considered mundane, but it is essential that they be done promptly if the specimens and data are to be properly saved.

The multiple demands of the overall expedition provided both benefits and constraints to the terrestrial vegetation survey. The benefits included the activities of the bird and turtle inventory teams who were able to quickly assess the smaller islets. It helped that Beth Flint, who was responsible for the bird surveys, was fully familiar with the flora in this region. The only minor disadvantage of participating with a larger expedition was that there were a few times when conflicting transportation demands limited the time available for sampling.

\section{The Survey Methodology and Its Efficiency}

Several preliminary activities, carried out before the arrival in Ailinginae, were important in the terrestrial plant sampling program. One involved checking regional floras (e.g., Taylor 1950) for species lists. A set of air photos, obtained from the U.S. Fish and Wildlife Service, was very important in our transect planning.

The time available and the size of the survey team let us establish an overall view of the species at Ailinginae Atoll, as well as the distribution of these species on the major islets. Two different methods, described earlier, were used to identify the diversity of species found on each islet. This allowed us to mea- 
sure the difference between the traditional method by which the flora of Micronesia has been determined (collection of voucher specimen inventories by selectively exploring the forest of each islet) and the alternative methodology based on using randomly located transects.

Although the checklist surveys appear to be able to identify more, if not all, of the species present, they provided little more than a species list. Transects, although missing more species, provided a richer data set about the forest structure and species densities. In some cases, the transects forced the exploration of areas that were difficult to reach due to the dense, nearly impenetrable vegetation in some areas. We recognize that most vegetation studies are done as a two-step procedure (a checklist survey followed by transect or relevé studies). In our case, the time limitations imposed by the expedition structure required that we do these two methods at the same time. Although the checklist surveys bring back voucher specimens, an essential documentation element, the transect surveyors can focus on collecting detailed data on the vegetation structure. Clearly, the two methods complement each other in the type of vegetation we surveyed and we therefore recommend that a combination of survey methods be used in future exploration studies.

\section{Anthropogenic Activity}

We expected to locate more evidence of anthropogenic disturbance than we actually found. It was remarkable that we found no weeds on any of the islets. There are several highly invasive species on nearby Rongelap Atoll: Chaemaesyce prostrata (Ait.) Small, Conyza canadensis (L.) Cronq., Bidens pilosa L., Phyllanthus amarus Schum \& Thonn., Cenchrus echinatus L., and Eragrostis tenella (L.) P. Beauv. ex Roem. \& Schult. As Ailinginae Atoll is visited by more people it is likely that some unwanted plants will invade. Our survey demonstrates the condition of the islets before such an event and might serve as a baseline to monitor the spread of an invasion. We feel that this is an important reason to have collected detailed data (most of which was not used in this report) and to make it available with voucher specimens for future surveys.

\section{CONCLUSIONS}

This study supports our view that the PABITRA network will benefit from the addition of studies on atolls. A full PABITRA team approach, as proposed in the PABITRA manual (Biodiversity Assessment of Tropical Island Ecosystems, PABITRA Manual for Interactive Ecology and Management [D. MuellerDombois, K. W. Bridges, and C. C. Daehler, eds.] scheduled tentatively for publication in 2005; the book contents are available at http://www.botany.hawaii.edu/pabitra), is likely to bring together the resources that will show the full value of how these small areas have been able to support both biological diversity and human populations over long periods of time.

\section{ACKNOWLEDGMENTS}

Mayor James Matayoshi and John Fysh of the Rongelap Atoll Local Government proposed the idea of this research and made it happen. We thank the other members of our field research team, Jodi Stevens, Jon Stevens, and Carrie Harrington, for their hard work and focus in gathering the data presented here. The cooperation and assistance of the other expedition teams, headed by Jim Maragos of the U.S. Fish and Wildlife Service, was essential to the success of the survey. We are grateful to Cliff Morden for his assistance in identifying the grass species. The major portion of the funding for this expedition came from the Rongelap Atoll Local Government. Further assistance was provided by the U.S. Department of the Interior. The individual researchers generally supported their own transportation to the Marshall Islands as well as the cost of their survey activities.

\section{Literature Cited}

DMA. 1995. Ailinginae Atoll, scale 1:72,500, hydrographic chart 81557. 2nd ed. De- 
fense Mapping Agency, Bethesda, Maryland.

MacArthur, R. H., and E. O. Wilson. 1967. The theory of island biogeography. Princeton University Press, Princeton, New Jersey.

Mueller-Dombois, D., and F. R. Fosberg. 1998. Vegetation of the tropical Pacific islands. Springer, New York.

Muller, F., and N. Vander Velde. 2001. Overview of the Marshall Islands' forest resources. In L. Thompson, ed. State of forest and tree genetic resources in the $\mathrm{Pa}$ cific islands, and sub-regional action plan for their conservation and sustainable use. Pacific Subregional Workshop on Forest and Tree Genetic Resources, Apia, Samoa, 1999. FAO, Forest Resources Division, Rome.
SAS Institute, Inc. 1995. SAS procedures guide. Cary, North Carolina.

Simon, S. L., J. C. Graham, and S. D. Terp. 2002. Uptake of $40 \mathrm{~K}$ and $137 \mathrm{Cs}$ in native plants of the Marshall Islands. J. Environ. Radioact. 59:223-243.

Stoddart, D. R. 1992. Biogeography of the tropical Pacific. Pac. Sci. 46:276-293.

Taylor, W. R. 1950. Plants of Bikini and other northern Marshall Islands. University of Michigan Press, Ann Arbor.

Thomas, P. E. J., F. R. Fosberg, L. S. Hamilton, D. R. Herbst, J. O. Juvik, J. E. Maragos, J. J. Naughton, and C. F. Streck. 1989. Report of the northern Marshall Islands diversity and protected areas survey. East-West Center in association with South Pacific Regional Environmental Programme, Noumea, New Caledonia. 